\title{
CAMERA-BASED DETECTORS AS AN ALTERNATIVE TO DETECT TRAINS IN A LEVEL CROSSING IMPLEMENTATION
}

\section{DETEKTOR BERBASIS KAMERA SEBAGAI ALTERNATIF PENDETEKSI KERETA PADA IMPLEMENTASI PERLINTASAN SEBIDANG}

\author{
Hilda Luthfiyah¹, Okghi Adam¹, Teddy Anugrah¹, Gilang Mantara1 \\ ${ }^{1}$ Center of Technology for System and Infrastructure of Transportation, \\ Agency for the Assessment and Application of Technology \\ e-mail : hilda.luthfiyah@bppt.go.id
}

\begin{abstract}
Based on data from Indonesia Directorate General of Railways in 2017, it is mentioned that the problems at the level crossing of railroad tracks are mostly caused by human error factors themselves. The current train headway and the crossing system that is still operated manually can increase the potential for accidents. Therefore, the development of alternative camera-based detectors to support the railroad crossing automation system is needed at this time. The development of this camera-based train detector uses the basic program You Only Look Once (YOLO), where YOLOv3 has proven to be accurate enough to detect moving objects. The development results show promising results for several types of alternative trains.
\end{abstract}

Key Words : Detectors; Train; YOLOv3

\begin{abstract}
Abstrak
Berdasarkan data dari Direktorat Jenderal Perkeretaapian tahun 2017 disebutkan bahwa permasalahan pada perlintasan sebidang rel kereta api banyak disebabkan oleh faktor kesalahan manusia itu sendiri. Headway kereta saat ini yang demikian rapat, serta sistem palang pintu perlintasan yang masih dioperasikan secara manual dapat meningkatkan potensi terjadinya kecelakaan. Oleh karena itu, pengembangan alternatif detektor berbasis kamera untuk mendukung sistem otomatisasi palang pintu perlintasan kereta api sangat dibutuhkan saat ini. Pengembangan pendeteksi kereta berbasis kamera ini menggunakan program dasar You Only Look Once (YOLO), dimana YOLOv3 telah terbukti cukup akurat untuk mendeteksi objek bergerak. Hasil pengembangan menunjukkan hasil yang menjanjikan untuk beberapa jenis alternatif kereta.
\end{abstract}

Kata kunci : Detektor; Kereta; YOLOv3

Received: 06 April 2020, Revised: 07 July 2020, Accepted: 09 July 2020.

\section{INTRODUCTION}

The operational system of a railroad crossing in Indonesia is still operated manually, meaning that the closing and opening of the railroad crossing depend on the railroad crossing guard. The increasingly tight headway of the train if it is not matched by increased safety will potentially lead to accidents on vehicles passing the level crossing. Based on data from the Directorate General of Railways issued in 2017, the accidents that occur at a level crossing result in the number of fatalities both dead to minor injuries at least 50 people each year. The most common cause due to human error is that a late crossing gate guard closes a 
doorstop or a crossing vehicle crosses a closed doorstop.

It is written in the Government Regulation number 61 of 2016 that at the intersection of parcels between rail lines and roads, hereinafter referred to as the intersection of parcels used for general or special traffic, road users must prioritize train travel. To support this, the construction of a railroad doorstop system automatically is a must. This system is expected to reduce the occurrence of accidents that often occur at the railroad crossings.

The automation system of the railroad crossing is done by installing detectors at each end of the railroad crossing to detect trains that will cross the level crossings. When the train is detected on the detector, the system provides information in the form of turning on the notification sound and flashing yellow light as a warning sign to the driver who will cross the level crossing that there will be a train will pass and the doorstop will immediately close. It is expected that road users have slowed down to stop the vehicle behind the crossing door. The system that was built was integrated with automatic doorstop equipment which closed if there was detected a train would pass.

The first sub-system in the automatic doorstop system is the train detector that can detect and recognize trains that pass on the tracks before going through level crossings. During this Train wireless detector technology used is the type of Lidar, Wireless Image Transmission System, or Laser Scanner ${ }^{3,}$ 5.) This equipment is used to detect the presence of objects that are at the level crossing. Also, studies are using Inductive Wires as hardware for the detection of trains that are installed on the side of the railroad before the train crosses a level crossing.

In this paper, the research developed is the detection of objects crossing the tracks using a camera with image processing. This image processing detects and recognizes objects that pass on the rails using machine learning methods. The object in question is a train that can be distinguished by type based on classification. The research methodology was carried out by collecting data on railway video collections that crossed the tracks. The video obtained must first be converted into an image. Then labelling the reading of train objects from various sides. After that, the training data is performed using darknet 53 so that the parameter configuration is obtained for testing the data. From the testing data, it is obtained the accuracy of image recognition using Yolov3.

\section{OBJECT DETECTION USING YOLOV3}

You Only Look Once (YOLO) is a program used for object detection and recognition in real-time. YOLO has an architecture consisting of many layers using Convolutional Neural Network (CNN). In this study, image processing for detection and recognition of Train images based on Darknet 53 network. Darknet 53 contains 53 layers for extracting deep neural networks ${ }^{10)}$.

YOLO divides the input image into the $S x$ $S$ grid. Each cell grid can only predict one object (B bounding boxes and confidence). YOLOv3 predicts the objective value of each bounding box using logistic regression. So, the total $S \times S \times B$ box can be predicted ${ }^{11)}$. The detection of objects in the bounding box based on a predetermined threshold is a minimum value of 0.6 . The object will be detected if the value is more than the minimum threshold value. Bounding box contains the object and the probability of $\mathrm{C}$ for each class of object that has been determined. In one picture a combination of several classes can occur so that it can be calculated the possibility of the presence of each class in the predicted box. Figure 1 is an example of an illustration of Train image input extraction using YOLOv3.

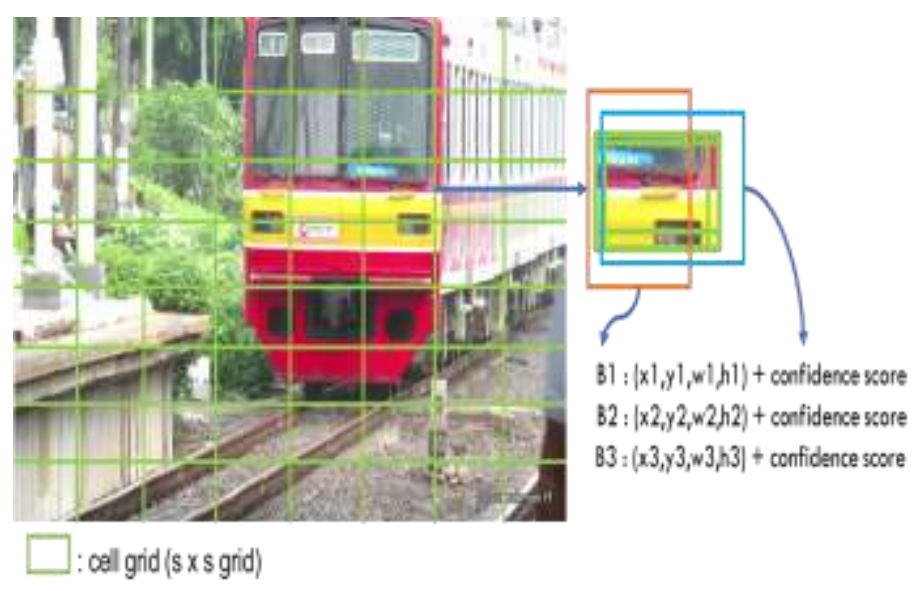

Figure 1.

Vector Correlation of Train

Based on the explanation above, the output obtained from the YOLO network is a vector ${ }^{8)}$ :

$(S \times S \times(B * 5+C))$

where $S \times S$ is the grid size, $B$ is the bounding box of each cell that will be predicted (using 3 boxes on each scale, then $B$ has a value of 3 ) and $C$ is the number of predicted classes. "5" for 4 bounding box offsets, 1 predicted object, and $\mathrm{C}$ is the prediction class ${ }^{7}$. 


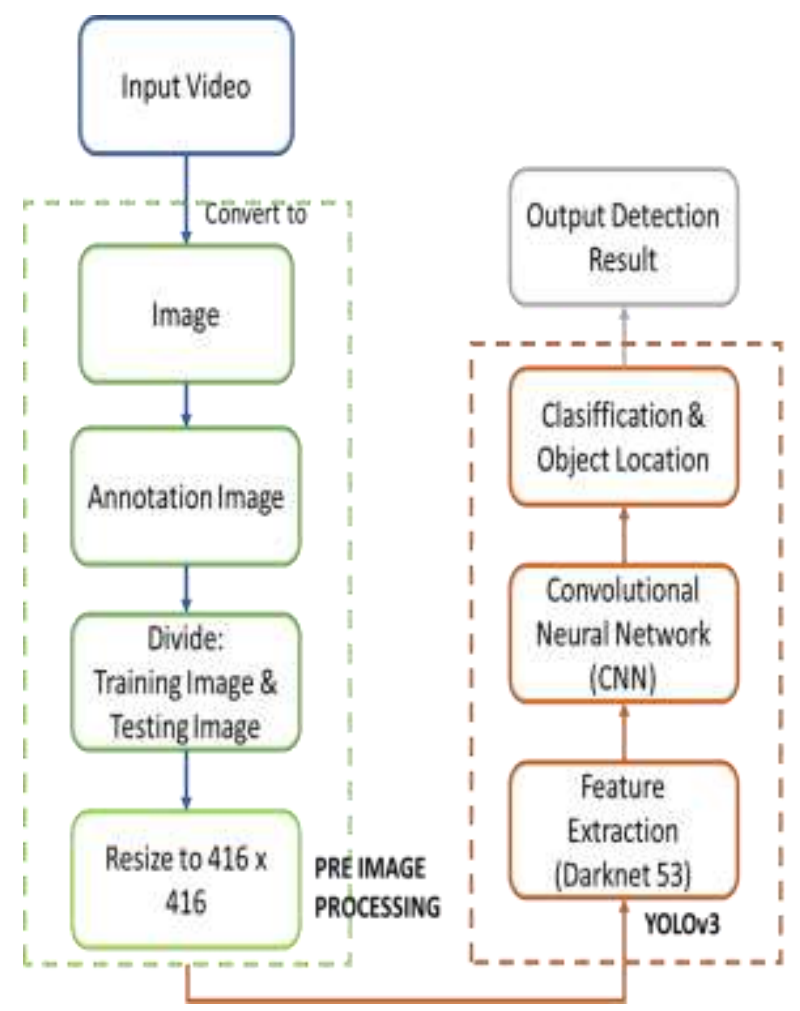

Figure 2.

YOLOv3 workflow

\section{OBJECT DETECTION ACCURACY}

The level of accuracy in object detection and recognition can be measured by several parameters ${ }^{1)}$, namely:

- Intersect Over Union (IoU)

IoU is a method of measuring the truth of objects based on overlap values between bounding boxes and ground truth. The threshold used in object detection is 0.6 for each class of train. If $\mathrm{loU}>0.6$, it is valued as the destination train class.

- Mean Average Precision (mAP)

Used for performance evaluation in detection-accuracy. The mAP value is obtained from Recall and Precision measurements then plot the 2 items curve. The area under the curve is the AP area. The mAP is calculated from each prediction and then averaged.

\section{DATASET CLASSIFICATION}

At present, there is no dataset available for trains in general and specifically operating in Indonesia. The train image data is taken from a YouTube video that illustrates several types of trains operating in Indonesia. Then the video data is converted into images. The types of trains used for classification are:

a) KRL / KRD, Kereta Rel Listrik (KRL) is a type of passenger train that serves the urban transportation system (short distance). The KRL is a type of self-driving train with a source of electricity through upper flow electricity. The type of $K R L$ that is taken is operating in Jabodetabek. Kereta Rel Diesel (KRD) is a type of self-driving passenger train using one or more diesel engines as a driving motor. KRL / KRD serves as one classification because they both have similar shapes.

b) Regular trains are passenger trains that serve long-distance passengers between provinces, consisting of locomotives with 8-10 passenger cars filled with passengers.

c) Mesin Perawatan Jalan Rel (MPJR) are railways used to maintain railroads. Serves to condense and spruce up the composition of rocks under the tracks or around the tracks, weld rails, etc. Shaped self-driving carriage with a striking yellow colour.

d) Locomotives are part of the train cars equipped with engines to drive trains. The types of engines in locomotives are varied, namely mechanical diesel, electric-diesel, and hydraulic diesel.

e) Freight trains are trains used to transport goods (cargo) in the form of containers.

f) Fuel trains are engine fuel transport trains.

g) Flat carriages are series of freight trains that are not carrying containers. The circuit consists of a locomotive as a driver and a series of carriages arranged on a basic floor deck mounted above the bogie. 


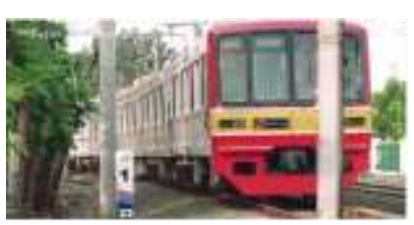

(a)

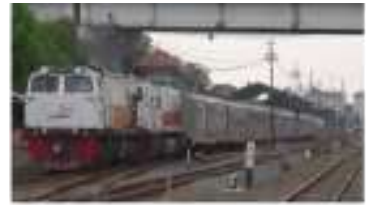

(b)

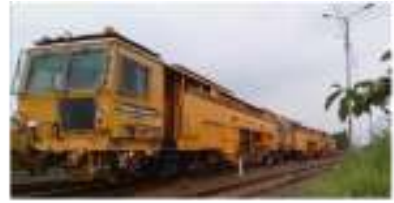

(c)

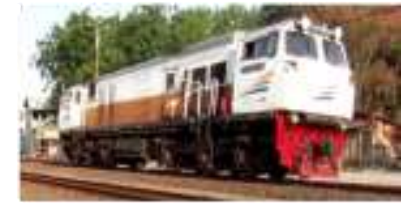

(d)

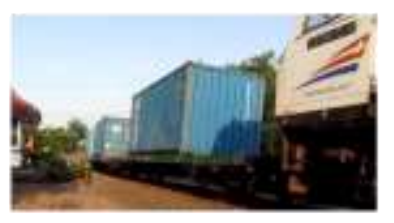

(e)

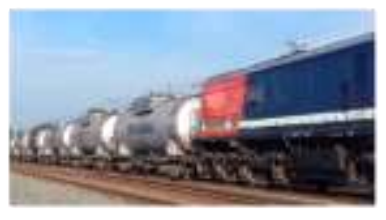

(f)

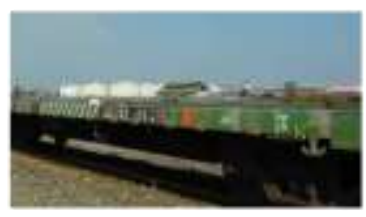

(g)

Figure 3.

Classification of Train Datasets (a) KRL / KRD (b) Regular Trains (c) MPJR (d) Locomotives (e) Freight Trains (f) Fuel Trains (g) Flat Cars

\section{DATASET CHARACTERISTICS}

Dataset images of various types of trains as shown in Figure 3 are taken from YouTube in the condition of the morning until the afternoon with fine weather. Shooting is not fixed with only one side of the rail, also from the two sides of the rail. Dataset images taken from a single track and double track crossings. To increase the accuracy of the data, images of trains that are passing are taken from the straight track rail as well as in the curved track. Retrieval of data is not limited to crossings, not one plot but also level crossings. This was done so that it could increasingly represent the real condition of the field conditions wherever the train passed.

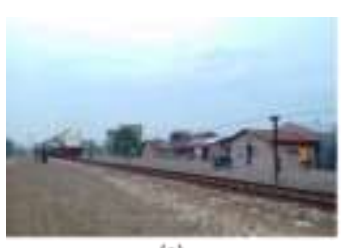

(a)

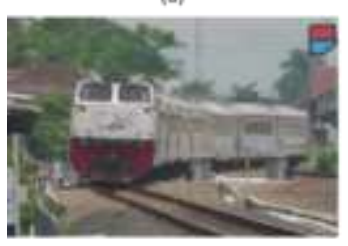

(c)

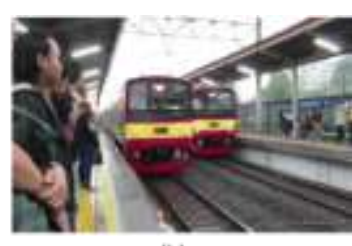

(b)

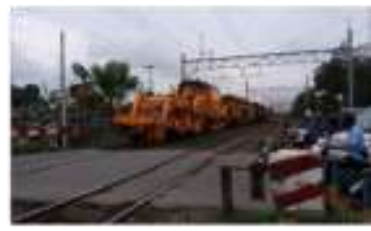

(d)
Figure 4.

(a) bright, straight rail, single-track trains (b) double-track trains (c) trains with curved rails (d) trains through level crossings

\section{CONFIGURATION}

When planning the classification of trains using 8 types of trains, in fact in this study using 7 types of trains, namely: KRL / KRD, regular trains, MPJR, locomotives, freight trains, fuel trains, and flat carriages. The total images used in the dataset are 1895 images. Each category is represented by at least 100 images. Data on train types in Indonesia are taken randomly from YouTube videos. This video is then converted to JPG format. The converted image is $1280 \times 720$ pixels.

The following stages of image processing using Yolo begin with Pre-processing ${ }^{4}$. Preprocessing is done next is to detect objects as well as annotate each image using labelling tools with the format. txt containing <objectclass $><x\rangle\langle y\rangle<$ width $><$ height $>$ stored in the same directory as the image. Detect with this annotation to provide a bounding box for the intended class of train image.

<object-class> : sequence number of the intended class

$\langle x\rangle\langle y\rangle\langle$ width $\rangle$ height $\rangle$ : coordinate location of the object and width of the object height.

\section{$\begin{array}{lllllll}0 & 0.705469 & 0.372222 & 0.589063 & 0.741667\end{array}$}

Figure 5.

Image Annotation with Format txt

After annotating images on all image data for each class, the data is randomly divided into training files and testing files. The testing file is used for data validation from the data training conducted. Image training consists of 1723 images and the testing file contains 172 images. Each type of file must be represented by each class. Testing files and training files are saved in .txt format. Then create a file with the format. Names that contain 8 classifications of the train in question. 
Camera Based Detectors as an Alternative to Detect trains in a Level Crossing Implementation (Hilda Luthfiyah, Okghi Adama, Teddy Anugraha, Gilang Mantara)

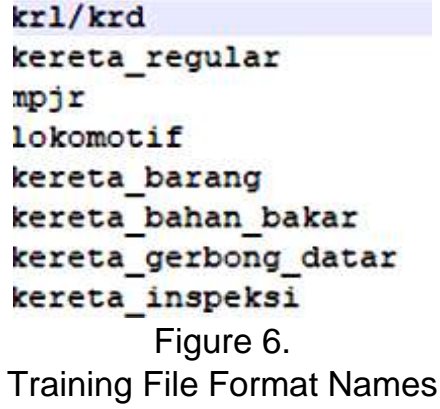

Training File Format Names

From each format that has been made before, then the .data format is created containing 8 classes to be tested, several images that will be trained in train.txt format, several images for validation on test.txt, the name of the class in question, and backup.

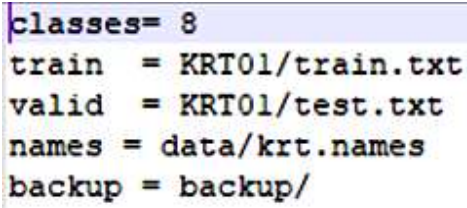

Figure 7.
Configure the file with the format .cfg with a batch size specification of 64 which means there are 64 images used in 1 iteration when updating parameters on a neural network. Resize the input image to $416 \times 416$. Each process is repeated for max batches 4000 times. With 8 classes used the vector filters are worth 39 based on equation (1) with the Bounding Box 3. Bounding Boxes are the number of anchor boxes that will be used. The learning rate is set at 0.001 , decreasing every 4000 iterations.

\section{SIMULATION ANALYSIS}

Training is done after all configuration parameters are filled. Training this dataset to produce one weight file. The results of the training dataset with a total of 1895 images and 4000 repetitions obtained $85.7 \% \mathrm{mAP}$ and current avg loss of 0.0851 which can be seen in Figure 8 below.

Example Training File Format data

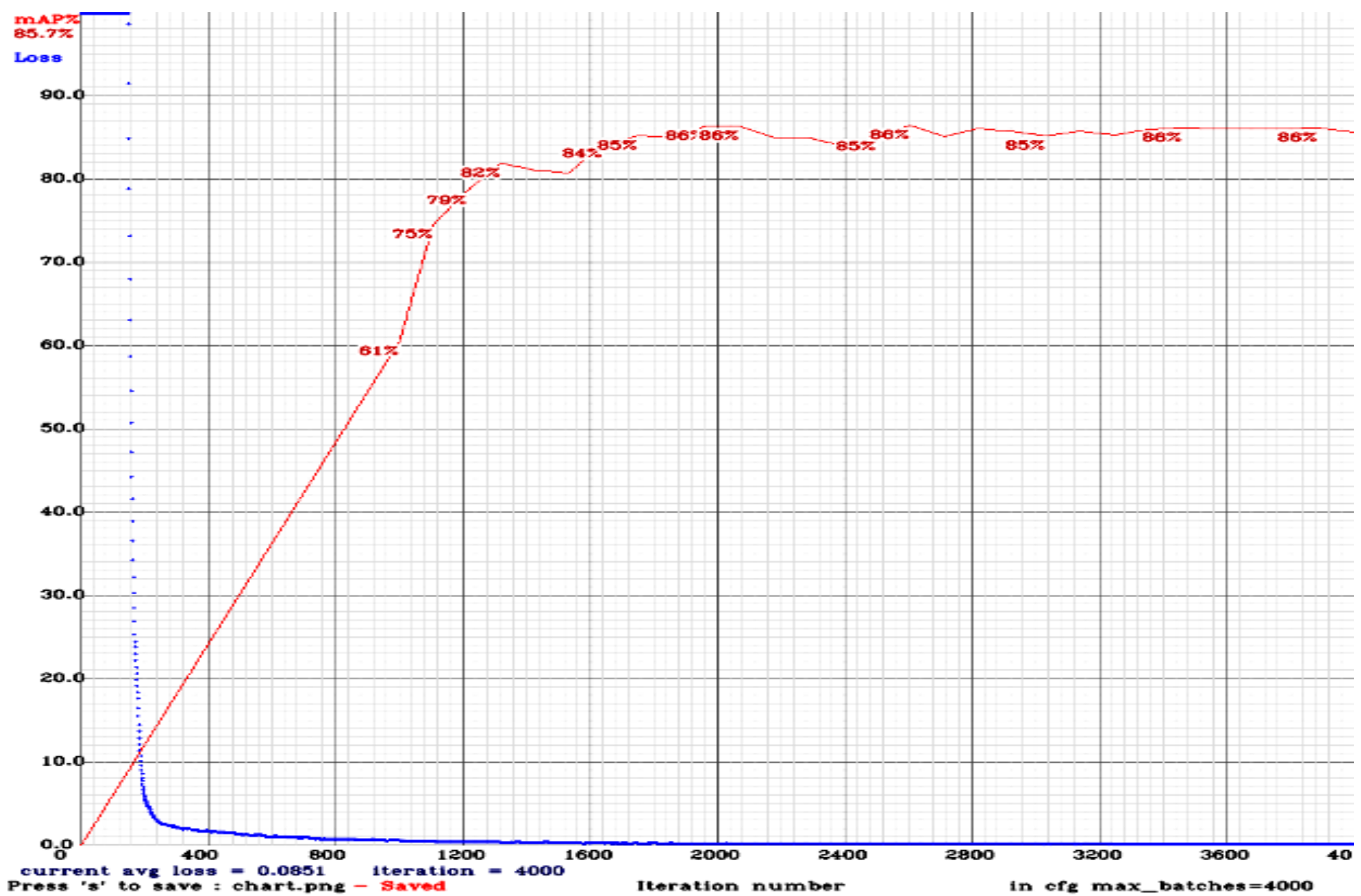

Figure 8.

Train Dataset Training Results 
Testing the results of the train dataset training using a new dataset that is different from the previous dataset. Testing the weight file using new videos taken randomly from YouTube. The type of video taken must be able to represent each of the previously identified train classifications. Train objects are considered to be detected if the value of loU $>0.6$ in each class. Here are the results of testing weights and datasets on several videos.

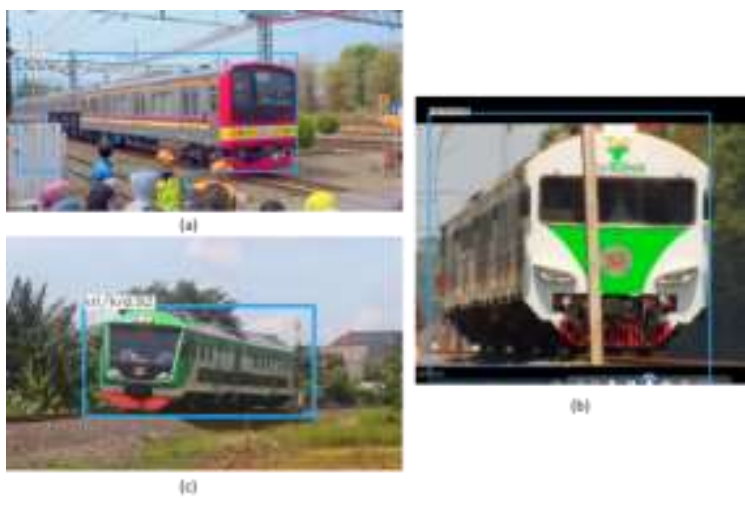

Figure 9

Testing Results for KRL-KRD (a) KRL class (b) Rail Clinic -KRD (c) KRD

Test results in the KRL-KRD class have an average value of $90-100$. This is influenced by the number of dataset images for KRL-KRD as many as 654 images. This means that the more images used as a dataset during training data, the higher the accuracy in detecting objects with that class. Even though the driving machines between KRL-KRD are different, but physically they are almost the same as self-driving cars with 6-8 cars, then they are grouped into one group. In Figure 9, the training dataset can classify Jabodetabek, Rail Clinic, and KRD $K R L$ types in the same group with the best IoU score of 100.

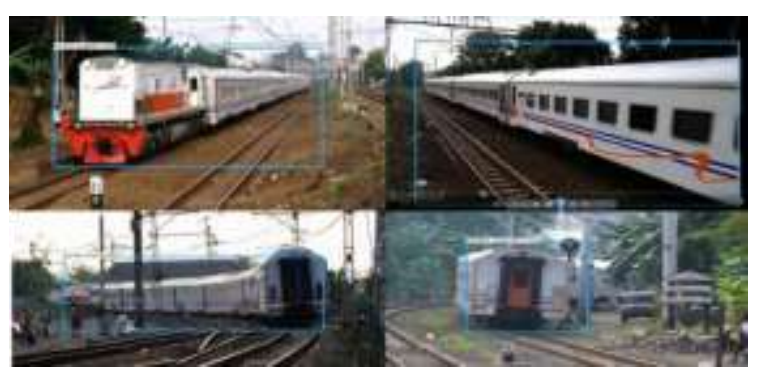

Figure 10.

Testing Results in the Regular Train class

The results of testing on the train class for regular trains can recognize objects not limited to one side of the train's appearance.
But you can recognize objects from the front, side, back, or bend the object can still be seen with an loU value $>90$.

The same is true for video train testing with the introduction of freight train objects containing containers. The results obtained; the training dataset that has been done previously can recognize freight trains with an loU value> 90 . The object recognition can detect objects from the front, side, bend, and still be able to recognize objects when the object is seen behind them.

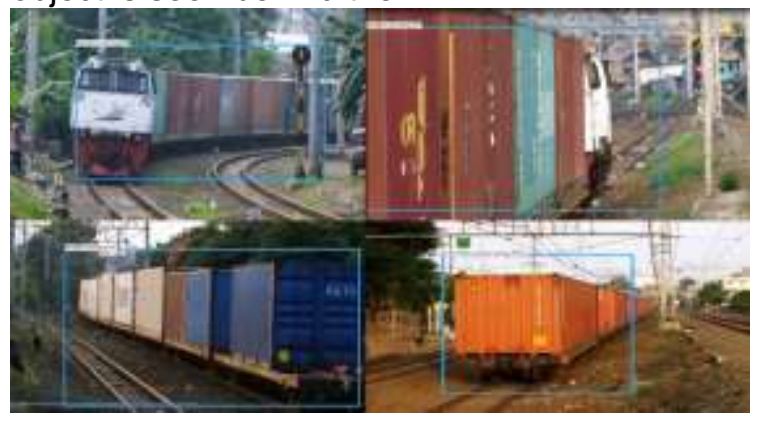

Figure 11

Testing Results for the Freight Train class

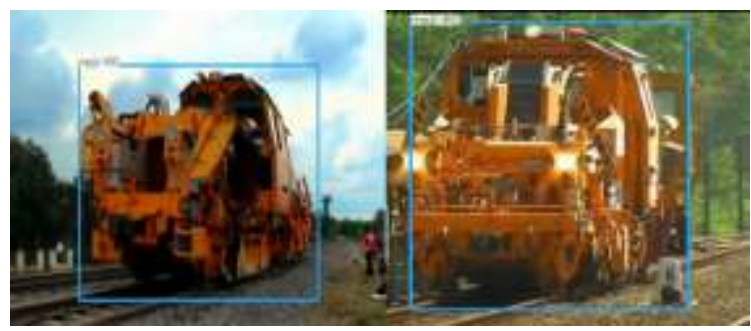

Figure 12.

Testing results for the MPJR class

When testing with the same video file source, the results obtained can detect MPJR objects with an loU value of 100 . This is because the specific MPJR shape is yellow with a train length equivalent to one carriage, so object detection and recognition are more precise.

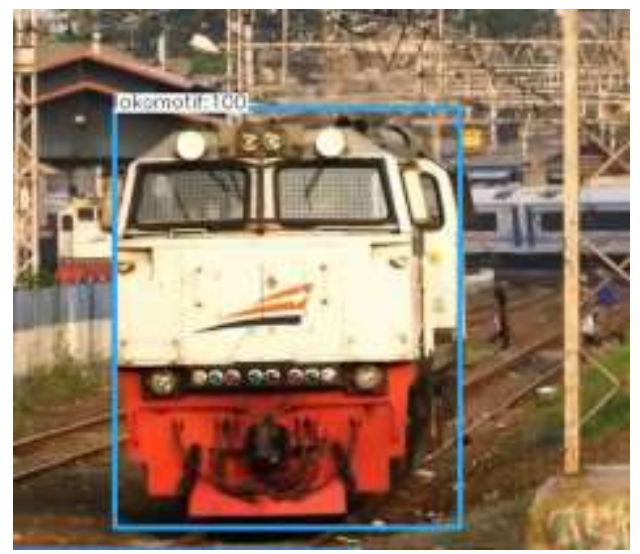

Figure 13.

Testing Results for the Locomotive class 
Another example in testing with locomotive object detection. One of the results obtained by loU is worth 100 in the position of the camera in front and sunny weather.

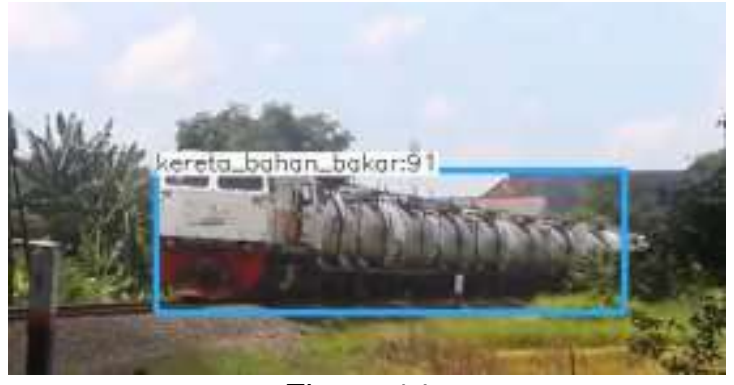

Figure 14

Testing Results in the Fuel Train class

The shape of the fuel train has a special shape of a tube with a colour similar to a regular train. This affects the results of the loU at the time of the introduction of the object. The best loU value achieved for the fuel train class is 91 . However, there are also many errors in the detection of being a regular train or freight train due to the similarity of the shape.
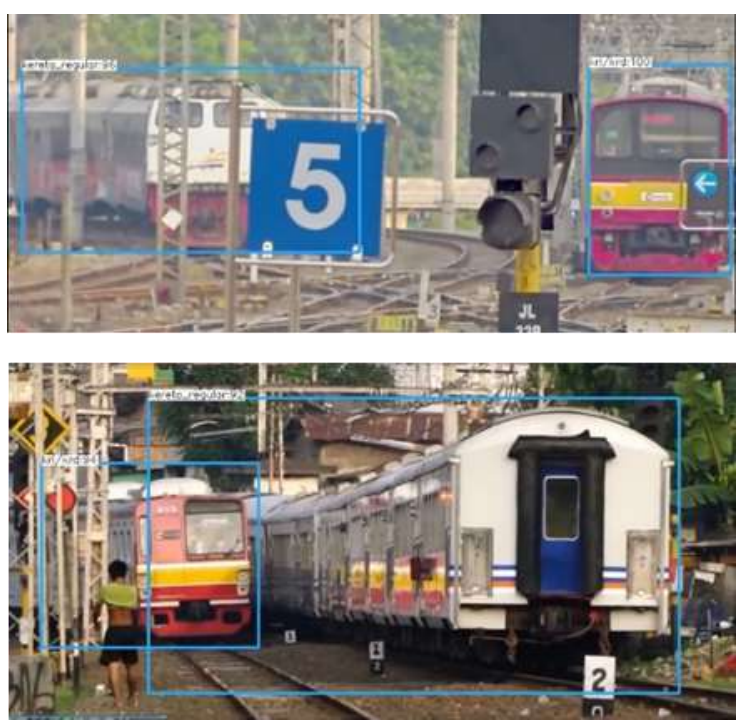

Figure 15

Testing Results When the Train Is Inserted

The results of the train detection test with the classification of 7 train classes, the results of the training dataset that were conducted were able to detect when there were two trains in one frame. Figure 15 shows the loU value achieved> 90 and can correctly identify each class, the KRL / KRD class with regular trains.

The average detection time during video testing takes $31 \mathrm{~ms}$ each time. Then in 1 second can process about 33 images.
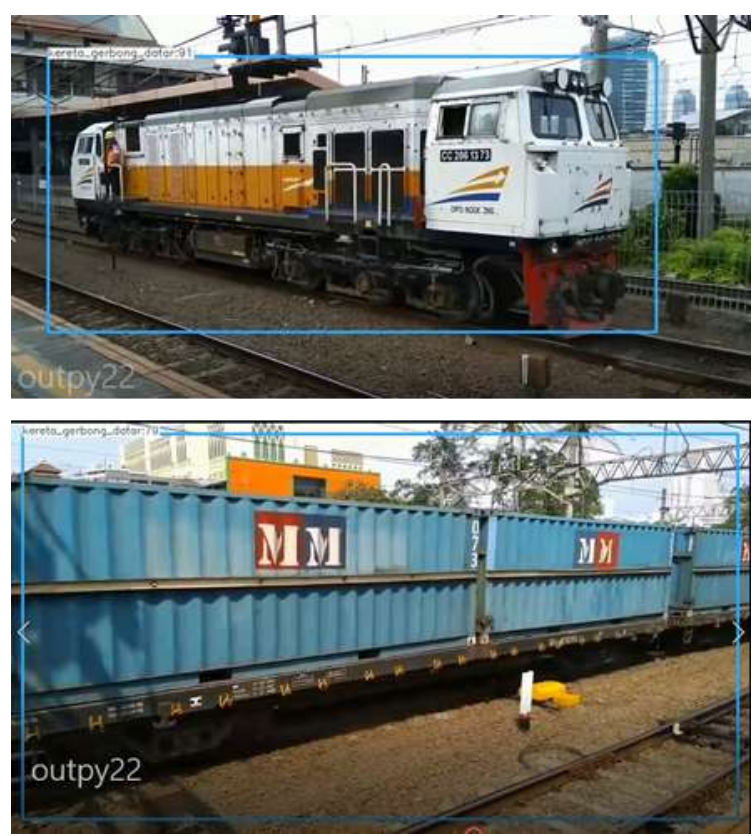

Figure 16.

Detection Results of Flat Carriage Car

In testing Yolov3 for flat carriage class, object detection is difficult to do because it influences the background object factor. As a result, many other object classes are detected as flat cars, even if there is no object indicated as flat cars.

\section{CONCLUSION}

In research on the development of camera-based detectors for train implementation using the YOLOv3 basic program, several things cause a decrease inaccuracy so that further development needs to be done including the following:

1. If it is dark as night and foggy.

2. Train objects are too far away.

3. Similar shapes and colours from each train class affect the accuracy of the IoU values obtained are decreased.

4. Detection of flat carriage class is difficult because it is influenced by the background.

\section{ACKNOWLEDGEMENT}

Thanks to PTSPT, BPPT that fully support this research related to the technical support and research funding.

\section{REFERENCES}

1. Rajendran, S. P., Shine, L., Pradeep, R., Vijayaraghavan, S., Real-Time Traffic Sign Recognition using YOLOv3 based 
Detector, Proc. $10^{\text {th }}$ ICCCNT 2019, India, July 2019.

2. Mao, Q-C., Sun, H-M., Lu, Y-B., Jia, RS., Mini-YOLOv3: Realtime Object Detector for Embedded Applications, IEEE Access Vol. 7, September 2019.

3. Chen, H., He, Z., Shi, B., Zhong, T., Research on Recognition Method of Electrical Components Based on YOLO V3, Proc. Special Section on Artificial Intelligence Technologies for Electric Power System, IEEE, November 2019.

4. Avramovic, A., Real-Time Large-Scale Traffic Sign Detection, 14th Symposium on Neural Network and Applications, Serbia, November 2018.

5. Kharchenko, V., Chyrka, I., Detection of Airplanes on the Ground using YOLO Neural Network, IEEE Int. Conf. Mathematical Methods in Electromagnetic Theory, Ukraine, 2018.

6. Lin, J., Sun, M., A YOLO-based Traffic Counting System, Conf. on Technologies and Applications of Artificial Intelligence, Taiwan, 2018.

7. Shahud, M., Praneetpolgrang, P., Bajracharya, J., Petcharee, S., Thai
Traffic Sign Detection and Recognition Using Convolutional Neural Network, IEEE, 2018.

8. Bismantoko, S., Luthfiyah, H., Putra, G. M., Hidayat, S., Tinjauan Teknis Deteksi Objek Berbasis Image Processing dalam Kasus Uji Coba Parkir Sepeda motor di Jalan, Jurnal online STMIK, Indonesia. 2018.

9. Artomonov, N. S., Yakimov, P. Y., Towards Real-time Traffic Sign Recognition via Yolo on a Mobile GPU, IOP Conf. Series: Journal of Physics: Conf. Series 1096, 2018.

10. Redmon, J., Divvala, S., Girshick, R., and Farhadi, A., You only look once: Unified, real-time object detection, Proceedings of the IEEE Computer Society Conference on Computer Vision and Pattern Recognition, 2016.

11. Redmon, J., and Farhadi, A., YOLOv3: An Incremental Improvement, 2018. [Online]. Available: http://arxiv.org/abs/1804.02767.

Accessed on January 2020 